\title{
Study of Abandoned Heritage Buildings from the Owners' Perspectives in George Town, Penang.
}

\author{
N.B. Mohd. Shukuri ${ }^{1}$, H. Awang ${ }^{2, a}$ \\ ${ }^{1,2}$ School of Housing, Building and Planning, Universiti Sains Malaysia, 11800, Penang, Malaysia
}

\begin{abstract}
Abandoning a heritage building is not a new phenomenon. In George Town, Penang specifically, there are many dilapidated heritage buildings that can be seen. These undeniable eye sores affect Penang's designation as a UNESCO World Heritage Site. This research aims to identify and assess the issues related to the dangerous hazards of abandoned buildings as well as problems involved in restoring these historical structures in order to determine how severe the current situation is. This study was also carried out to better understand the reasons why owners decide to leave heritage buildings unoccupied to the point that they became unsafe to inhabit. A total of six case studies were carried out with data collection focusing on the historical background of each site, clarification of the causes of neglect to each heritage building and plans made by respective owners towards the future of their properties. The majority of relevant information was gathered through semi-structured interviews.
\end{abstract}

\section{Introduction}

The historic city of George Town, Penang has been well known for being one of UNESCO's World Heritage Sites since $7^{\text {th }}$ July 2008 [1]. This contributes an enormous number of 1,904 units of enlisted heritage buildings covering 109.38 hectares of Core Zone and 150.04 hectares of Buffer Zone in George Town area alone [2]. Although most areas there are well preserved and have become enormous tourist attractions, there are still a number of buildings that remain unoccupied, neglected and have not received the same care. Despite the fact that Malaysia has established guidelines as well as regulations for conservation [3], how can there still be buildings that appear to be abandoned and not properly preserved as they should be for the benefit of others?

If a heritage building is left unoccupied for too long, the building will start to encounter defects much faster compared to conventional buildings due to its delicate and sensitive structure. Moreover, the fact that George Town is located particularly close to the coast means varying degrees of salt deterioration can easily be triggered, leading to the disintegration of a building's brickwork or worse, collapse of external walls. Other parts of the building that are prone to failure are deterioration of the timber structure and dampness problems that can later cause widespread moss to grow on the building, hence, damaging the building's structure [4]. Unfortunate as it may seem, abandoned historical buildings not only become unpleasant sights, but if not properly restored and cared for soon, they will completely lose their functionality.

\footnotetext{
${ }^{\mathrm{a}}$ Corresponding author : hanizam@usm.my
} 
The appearance of abandoned heritage buildings undeniably hurts the aesthetics of an area, especially when it comes to areas near main tourist attractions. For example, the abandoned shop houses along Prangin Road are currently being used as a temporary parking lot. Across from this abandoned lot, however, are located some magnificent, well-restored heritage shop houses along Maxwell Road. Such disagreeable sights must not be permitted to hurt the appeal of a centre for tourism, and George Town is definitely no exception. Therefore, the 3 objectives that this study strove to achieve were not just to identify issues and problems faced by owners in terms of restoring and maintaining heritage buildings, but also to determine the factors contributing to the owners' decisions to abandoned these buildings in the first place as well as to propose solutions to help owners overcome problems in abandoned heritage buildings.

\section{Methodology}

The first primary objective in conducting this research was to identify the owners of a few abandoned heritage buildings within George Town World Heritage Site, Penang. In order to obtain this data, a map plotting method was carried out using George Town World Heritage Map to locate the abandoned buildings within the core and buffer zones. Observations that were carried out revealed a variety of culturally significant structures ranging from British Colonial bungalows to Malay, Chinese and Indian architecture, aspects of which can still be seen within these abandoned heritage buildings.

\subsection{Observations of Abandoned Heritage Buildings around George Town}

Different stages of investigation were performed throughout this research. In order to fulfil the first objective, a map plotting method was carried out to identify where the abandoned heritage buildings are located. Observations were then done from street to street within the set conservation area as laid out by the Municipal Council of Penang Island's Draft Conservation Guidelines 2003 in both the Core Zone and the Buffer Zone.

\subsection{Observing the Conditions and Identifying Problems of Abandoned Heritage Buildings}
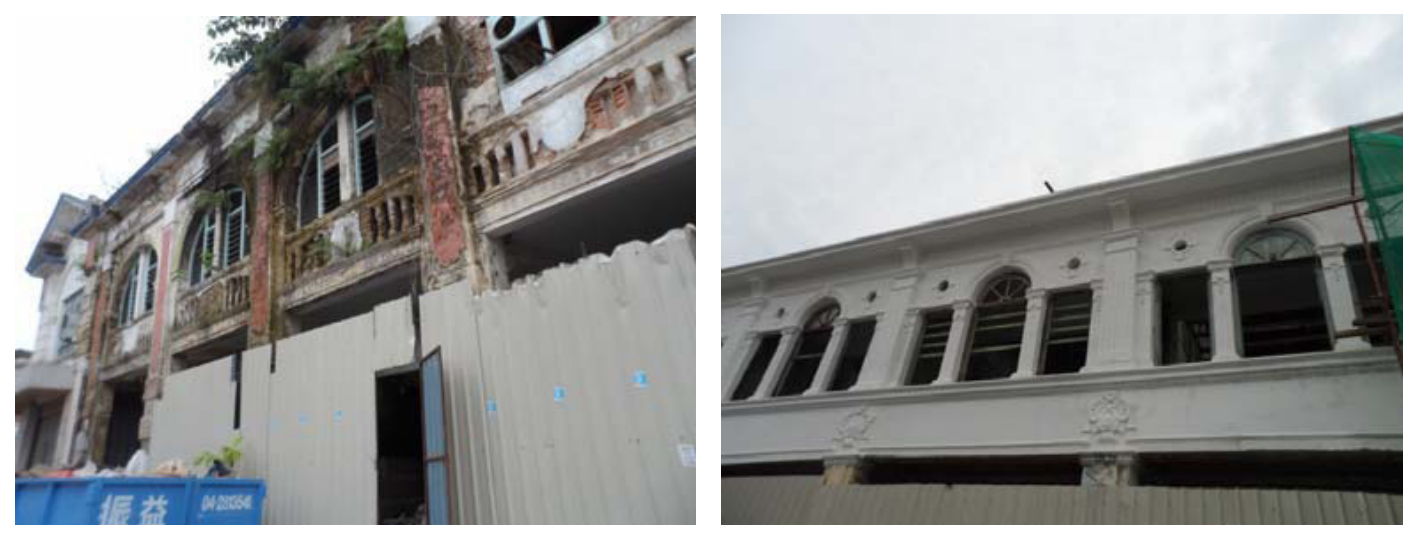

Fig. 2. Before (left) and after (right) restoration of shop houses on Phee Hoon Street

\subsection{Identifying Owners of the Listed Heritage Buildings}

For the next part of the research, an investigation was carried out to identify each abandoned heritage building owner who was willing to cooperate with the study. Even though there are a lot of abandoned heritage buildings in George Town, most of the owners were unavailable during the course of the study or did not respond to interview requests. Each building was recorded in a table and categorised according to its architectural style and location as shown below in Table 1. 
Table 1. List of Identified Abandoned Heritage Buildings in George Town World Heritage Site.

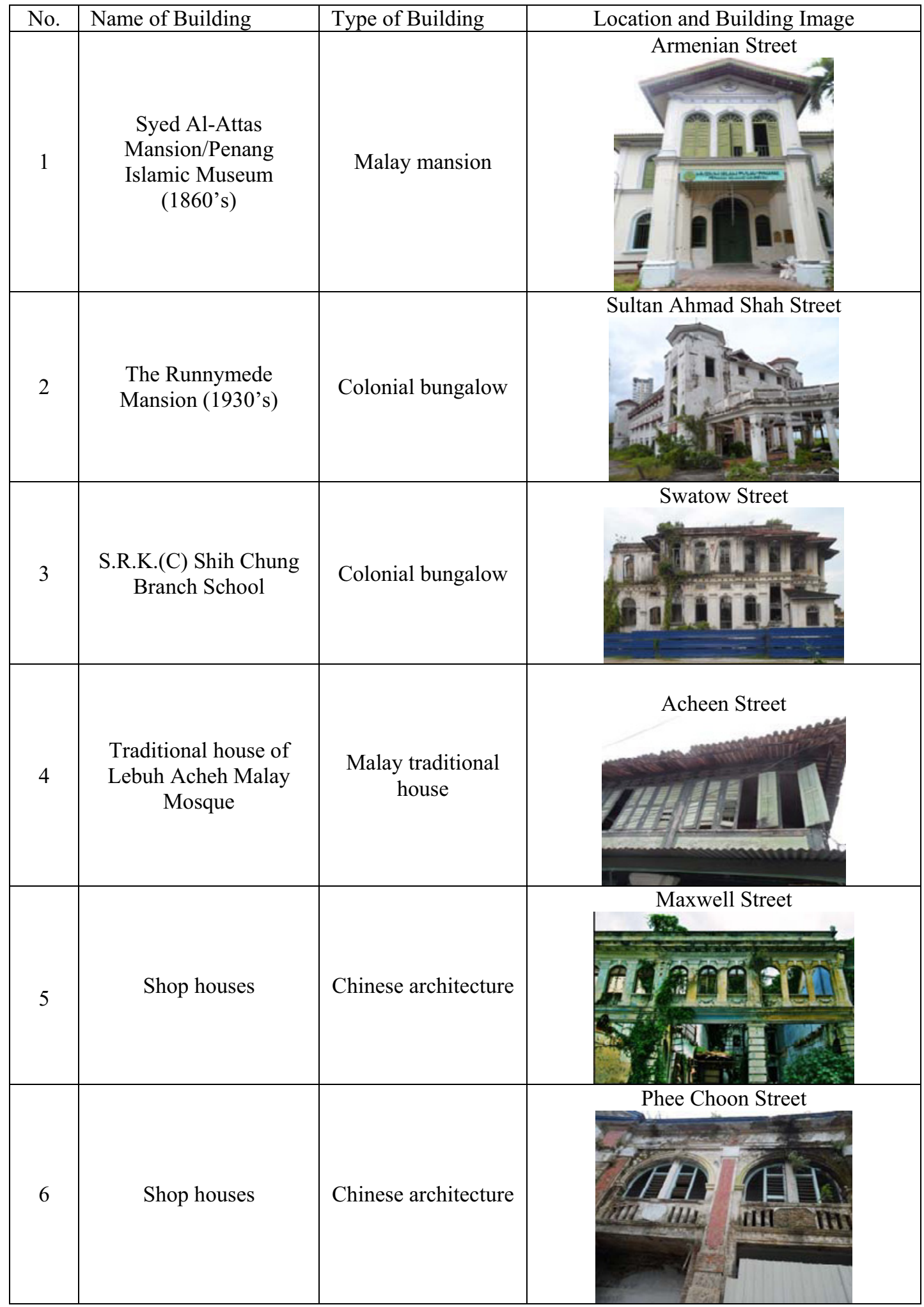




\subsection{Interviews with Building Owners}

For data collection purposes, in-person interviews were carried out in order to accomplish the first objective of this study which was to identify issues and problems faced by owners in terms of restoring and maintaining heritage buildings. Visible issues could be observed by accessing the abandoned heritage buildings, however, the main reason why these issues had arisen in the first place could only be clarified by the owners. Different heritage buildings faced different issues which were not only based on the buildings' functionality but also on the type of heritage building.

\section{Data Collection}

\subsection{Syed Al-Attas Mansion/Penang Islamic Museum (1860's)}

An interview was carried out with the Penang Islamic Foundation (Yayasan Islam Pulau Pinang) to clarify their problems in restoring the museum. When this research started, the heritage building had been abandoned for nearly three years. The reasons mentioned pointed to insufficient funds since they could not collect enough money to restore the building. However, since earlier this year, restoration of the building had finally begun and is expected to end by June 2014 . The main concern why the museum was not getting as many visitors as expected was because the location of the building was not one of the main tourist attractions. As a result, George Town World Heritage Incorporated has come out with an alternative plan by launching "Armenian Street's Got Talent" to help promote the whole area.

\subsection{The Runnymede Mansion (1930's)}

This magnificent Colonial Bungalow was passed down from the British Army to the Malaysian Military when Malaysia gained independence in 1957. However, in 2011 the military based was moved to a new location in Bukit Gedung, now known as Kem Tun Razak. An agreement was made between the Military and Warisan Pinang Sdn. Bhd. to hand over their property after the completion of construction at the new camp. For the past 4 years, the area has been abandoned due to a tight schedule to finish the new camp first. Plans for the future restoration of this heritage building have been made; it will be adaptively reused as an affordable hotel with a recreation centre offering a beautiful seaside view.

\subsection{Shih Chung Branch School}

The abandoned Chinese Branch School was built in the late 19th century and was originally called Goh Chan Lau, which means "5 Storey Bungalow." The magnificent mansion was home to an eclectic mix of styles which could be described as Chinese meets Malay meets Colonial architecture. The building later became Bellevue Hotel, also known as Raffles-by-the-Sea Hotel, which was an imitation of the famous Singapore Raffles Hotel. However, it was a failure and the hotel was closed not long after. Since 1915, the building was used as Pi Joo Girls School and was later renamed Shi Chung Branch School. The latest owner was Malaysia Vegetable Oil Refinery Sdn. Bhd, who bought the building for RM9.5million in 1993. Though it was intended to be developed as a 3 block columbarium of 9 to 10 storeys, it is now an abandoned building because of a state wide campaign against the plan led by the people of Penang.

\subsection{Traditional Malay House on Acheen Street}

This heritage house was built in the same year of the Acheen Street Mosque in the $19^{\text {th }}$ century. The house was originally built for the convenience of the mosque's committee members. Penang Heritage Trust conducted their last restoration on the building in 2006. However, since the last mufti moved out in 2010, the house has remained unoccupied while other committee members prefer to stay in the new houses built next to the heritage building. After having been left for so long, the house is now said to be unsafe as well as full of vandalism and graffiti from youngsters who hang out around the house. 


\subsection{Shop Houses on Maxwell Street}

The shop houses along Maxwell Street and Prangin Road were abandoned after the wet market beside the street was forced to close several years ago. Plans to develop the area into "Heritage Square" were announced by the Penang Development Corporation in 2012, but no action has been carried out up until now. This area was previously well known for its old Prangin Canal which connects Sia Buey to the sea. It was a spot where visitors loved to come for the wholesale shops and 24-hour food stalls. Prangin Road is now a busy thoroughfare that connects Penang Road to Dr. Lim Chong Eu Highway It is essentially the main road used by everyone who enters George Town. Sadly though, the abandoned heritage buildings there were turned into a temporary car park.

\subsection{Shop Houses on Phee Choon Street}

These 12 units of abandoned heritage shop houses are one of the major restoration projects being carried out at the moment by K. S. Oh Sdn. Bhd. This particular area is well known for its famous Hainan-style restaurants and even once had a Majestic Cinema. These heritage shop houses were built during the 1880's and named after Lee Phee Choon who was known as Penang's richest Chinese person at that time. Up until the 1980's, the Chinese community that lived there had become quite prosperous from conducting business in this famous area. However, customers stopped coming to Phee Choon Street after new food stalls with more comfortable facilities opened in the nearby area.

\section{Conclusion}

As a conclusion, the main outcome from the gathered information in this study points to the fact that not all owners inherited their buildings. Some were bought and restoration work was transferred from the previous owner. This became an issue for the current owners, where their lack of experience and knowledge about the conservation of historical structures lead them to abandon the building until they could gather enough resources and hire the right professionals to do the job. There were owners who put a lot of effort into providing preliminary plans for the restoration of heritage buildings. However, after estimating the required costs, they realised that the project would require more than they could afford. This contributed to their decision to abandon their heritage buildings for now until they can draw up enough funds to start the work. Besides insufficient funds, there were also some owners who were private developers who could not begin the restoration of their respective heritage building due to a tight schedule to finish work on other projects first. Some owners decided to abandon their heritage buildings because the surrounding area was found to be less desirable compared to others. It was pointed out that only the roads with famous tourist attractions were really good locations to invest in running a business. The only way owners could benefit from the area where their buildings are located was by providing temporary car parks to deal with traffic congestion and limited space in George Town.

\section{References}

1. Nomination Dossier, Historic Cities of the Straits of Malacca and Georgetown, Penang.

2. George Town World Heritage Inc. What We Do. [Online] available at: http://www.gtwhi.com.my/index.php/about-us

3. Municipal Council of Penang Island (MPPP). Guidelines for Conservation Areas \& Heritage Buildings

4. Watt D. (2006). Managing Biological Growth on Buildings. [Online] available at: http://www.buildingconservation.com/articles/bio/bio.htm 